\title{
一般口演 11
}

\section{ゼリーの舌押し潰し舆下時における舌圧発現と舌骨移動}

Tongue pressure production and hyoid excursion during squeezing and swallowing jelly

○村上和裕 ${ }^{1)}$, 堀 一浩 ${ }^{2)}$, 皆木祥伴 ${ }^{1)}$, 藤原茂弘 ${ }^{2)}$, 徳田佳嗣 ${ }^{1)}$

Simonne E. Salazar ${ }^{2}$ ，上原文子 ${ }^{2)}$ ，井上 誠 ${ }^{3)}$ ，小野高裕 ${ }^{1,2)}$, 前田芳信 ${ }^{1)}$

Kazuhiro Murakami $^{1)}$, Kazuhiro Hori ${ }^{2)}$, Yoshitomo Minagi ${ }^{1)}$, Shigehiro Fujiwara ${ }^{2)}$, Yoshitsugu Tokuda ${ }^{1)}$

Simonne E. Salazar ${ }^{2)}$, Fumiko Uehara ${ }^{2)}$, Makoto Inoue ${ }^{3)}$, Takahiro Ono ${ }^{1,2)}$, Yoshinobu Maeda ${ }^{1)}$

1) 大阪大学大学院歯学研究科顎口腔機能再建学講座有床義歯補綴学・高齢者歯科学分野

2) 新潟大学大学院医歯学総合研究科包括歯科補経学分野

3) 新潟大学大学院医歯学総合研究科摂食與下リハビリテーション学分野

${ }^{1)}$ Department of Prosthodontics, Gerodontology and Oral Rehabilitation, Osaka University Graduate School of Dentistry

${ }^{2)}$ Division of Comprehensive Prosthodontics, Niigata University Graduate School of Medical and Dental Sciences

${ }^{3)}$ Division of Dysphagia Rehabilitation, Niigata University Graduate School of Medical and Dental Sciences

\section{I. 目的}

咀嚼・嚥下障害患者に提供する嚥下調整食は規格によ り食品物性が定められている ${ }^{1)}$.また,「歯ぐきで潰せる」 や「舌で押し潰せる」など咀嚼能力が低下した患者が代 償的に行う食塊形成も考慮されているが，こうした食塊 形成過程のバイオメカニクスに関する研究は少ない. 本 研究では嚥下調整食として頻用されるゼリーの「舌によ る押し潰し」とその後の鱟下における舌圧発現と舌骨移 動の協調性を調べるとともに，ゼリーの初期物性がそれ らに及ぼす影響を定量的に評価することを目的とした。

\section{II. 方 法}

\section{1. 被験者}

摂食興下障害の既往のない健常成人男性 16 名とした。 (平均年齢 $30.9 \pm 3.0$ 歳)

\section{2. 測定装置}

舌圧測定には硬口蓋に貼付する Swallow scan system (ニッタ,大阪）の舌圧センサシート（図 1) を使用した。 燕下造影検査 (VF) にはARCADIS Avantic (Siemens, München）を用い, 30 フレーム/秒で撮影後, 二次元 データ解析ソフト DippMotion Pro Ver2.24d (ディテク ト, 東京）を用いて解析した。舌圧測定と VF は計測時 間の同期を行った。

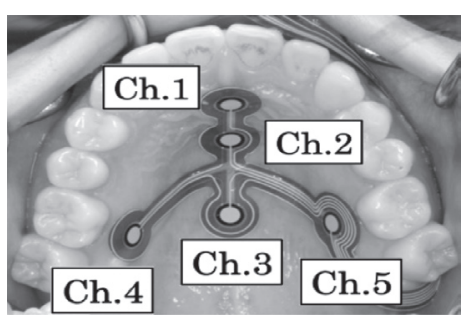

図 1 舌圧センサシートと各Ch. の位置

\section{3. 被験試料}

$5 \mathrm{ml}$ のゼリー試料を用いた。ゼリー試料はジェラン ガムを主成分とし，破断荷重と破断歪を 2 段階ずつ調整 した 4 種類のゼリー試料 $5 \mathrm{ml}$ （三栄源エフ・エフ・アイ, 大阪）を使用した。造影剂にはイオパミロンを使用した (表 1 ).

\section{4. 測定方法}

被験者は座位にて $5 \mathrm{ml}$ の試料を口腔底に含み，験者 の指示により舌による押し潰しの後嚥下した。舌押し潰 し回数と曣下のタイミングは制限を設けなかった。測定 回数はゼリー試料を各 2 回ずつとし, 測定順序はランダ ム化した。

\section{5. 分析方法}

舌圧測定では, 舌押し潰し 1 回目と曣下時の舌圧最 大值，持続時間，タイムポイント（舌圧の Onset, Peak, 


\begin{tabular}{c|r|c}
\multicolumn{3}{c}{ 表 1 2 ゼリー試料の物性 } \\
試料 & \multicolumn{1}{|c}{ 破断荷重 (N) } & 破断歪 (\%) \\
\hline Soft, Brittle & $9.71 \pm 0.13$ & $43.31 \pm 0.34$ \\
Hard, Brittle & $28.70 \pm 1.00$ & $46.16 \pm 1.08$ \\
Soft, Deformable & $9.73 \pm 0.94$ & $74.34 \pm 1.67$ \\
Hard, Deformable & $29.40 \pm 0.99$ & $78.71 \pm 1.19$
\end{tabular}

Offset), VF では舌骨最高移動速度, 移動距離, 移動時 間, タイムポイント (舌骨移動の Onset, 最前上方位, Offset）を分析項目とした. 同一試料内の舌圧のCh. 間 とタイムポイント間の比較, ゼリー試料間の各項目の比 較には繰り返しのある一元配置分散分析と Tukeyの方 法を用い，有意確率は $5 \%$ とした。

\section{III. 結果及び考察}

\section{1. 舌圧発現と舌骨移動の協調性}

舌押し潰し 1 回目では Ch.2（口蓋正中中央部）にお ける舌压最大值と持続時間が全 $\mathrm{Ch}$. の中で最大であっ た。また，舌圧の Onset と Peak は Ch. $2 \rightarrow$ Ch. $1 \rightarrow$ Ch. 3 , 4, 5 の順に発現し, 各 Ch. の Peak は舌骨が最前上方位 に位置する間に発現した（図 2 )。これらのことから， 口蓋正中中央部は舌押し潰しの起点かつ最大の力点であ ると考えられた。 また, 舌押し潰しでは舌圧発現と舌骨 移動が協調することが示唆された。

嚥下時の舌圧 Onset の順序は, Ch. $1 \rightarrow$ Ch. $2 \rightarrow$ Ch.4, $5 \rightarrow$ Ch.3 となり, Ch.1に扔ける舌圧と舌骨移動の Onset に時間差は認められなかった。また, 各 Ch.の Offsetは 舌骨移動のOffsetより有意に早く発現した（図 3 ). 以 上のことから, 舌が口蓋前方部から後方部へ規則的に接 触し, 舌骨移動が協調することで食塊を口腔から食道へ スムーズに移送することが示唆された。

\section{2. ゼリーの初期物性の影響}

舌押し潰しでは, ゼリーの破断荷重の増加や破断歪 の減少により舌圧最大值 (図 4), 舌骨移動距離は有意 に増加し, 舌圧持続時間とタイムポイントは延長する 傾向を認めた。燕下では，4 種類のゼリーのうち Hard, Brittle なものだけが他のゼリーよりも大きな舌骨の移 動速度と距離を要した。

以上の結果より, 舌押し潰し 1 回目に扔いては, ゼ リーの初期物性に応じて, 舌は口蓋との接触様相（強さ, 時間）を調整し，それにともなって舌骨移動も変化して いることが明らかとなった。しかし，そうした押し潰し 舌圧の調整にも関わらず，硬くてたわみにくい（破断荷 重が大きく, 破断歪が小さい) 初期物性のゼリーの場合 は, 嚥下咽頭期における舌骨移動に影響を及ぼし，嚥下 の負荷が大きくなったことが示唆された。

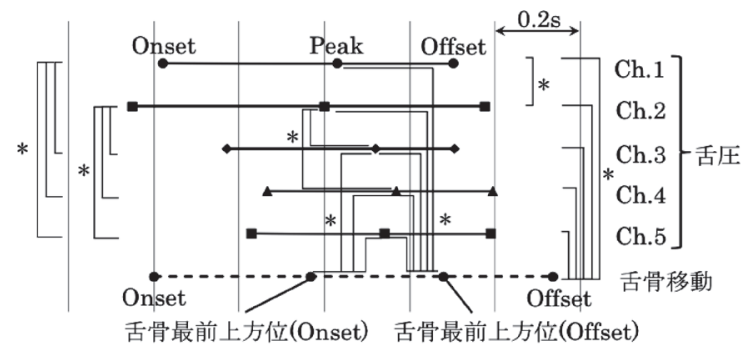

図 2 舌押し潰し 1 回目の舌圧発現と舌骨移動の協調

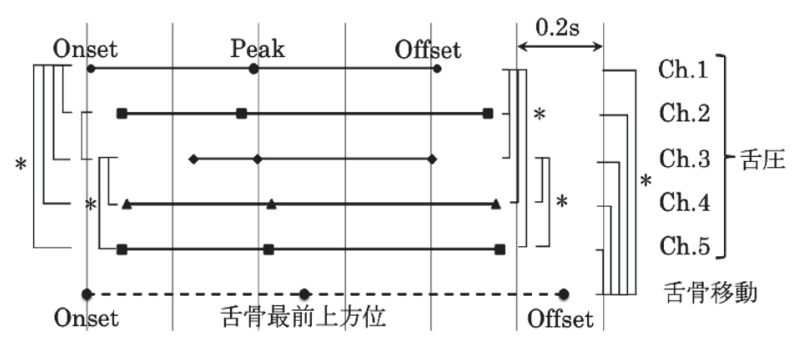

図 3 嚥下時の舌圧発現と舌骨移動の協調

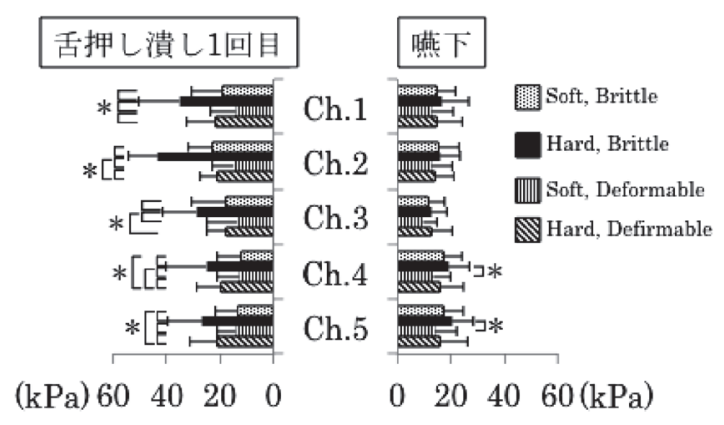

図 4 舌押し潰し 1 回目と嚥下時の舌圧最大値

本研究の結果は, 舌押し潰し燕下の口腔・咽頭器官の 機能的動態を定量的に示したものであり，今後嚥下調整 食の開発や提供の基準を確立する上で有益な情報を与え るものと考えられる。

\section{謝辞}

本研究の遂行にあたり，多大の御協力を賜りました三 栄源エフ・エフ・アイ株式会社 テクスチャーデザイン 研究室 船見孝博様，中馬誠様に深甚なる感謝の意を表 します。

\section{N. 文献}

1) 藤島一郎ほか。日本摂食嚥下リハビリテーション 学会嚥下調整食分類 2013. 日摂食嚥下リ八会誌 2013 ; 17 : 255- 267. 